\title{
Agroforestry and mobile local 'bank' system (Bank Kuriling) in Cianjur, West Java, Indonesia
}

\author{
Dede Tresna Wiyanti ${ }^{1}{ }^{*}$ \\ ${ }^{1}$ Lecturer at Department of Anthropology, Faculty of Social and Political Science, Universitas Padjadjaran \\ *Corresponding author: dedetresna06@yahoo.co.id
}

\begin{abstract}
Tunagan is a small hamlet in Wangunjaya Village, Cianjur, West Java, Indonesia. Tunagan Hamlet is isolated in a slope of Gunung Geulis in Cianjur. As in many other Indonesian village landscapes, Tunagan is dominated by agricultural and forest cover. This study is about the local banking system related to the agricultural practice of Tunagan People. This study was using the mix between quantitative and qualitative methods. The result of the study shows that people of Tunagan practice various type of agricultural systems, from wet paddy field, garden, and the mix between paddy field and garden. Moreover, people of Tunagan also practice agriculture on forest land. This type of agricultural practice is known as agroforestry. The diversity of agroforestry produce creates different techniques and periods of harvest. People of Tunagan have different time periods for selling their harvest produce, therefore earning cash at different times. But to go to the formal bank, they have to spend a lot time and money for walking and the ojeg ride. To solve this problem, people of Tunagan have a mobile bank system that approach people directly to their residence to collect cash called bank kuriling. This system does not only allow people to save but also to borrow money.
\end{abstract}

Keywords-Mobile Local Bank System, Kuriling, Tunagan, Agroforestry.

\section{INTRODUCTION}

\section{Agroforestry}

Agroforestry is defined as a system of land use in accordance with cultural practices and local environmental conditions (Whitten, et al. (1999) in Iskandar, 2001). In agroforestry systems, annual cultivated crops or jointly or by rotation, and even sometimes in multiple layers, allowing production conducted continuously. Agroforestry usually have a very dense structures such as natural forests that have ecological functions such as forests (Soemarwoto, 1984). In addition, agroforestry provides social benefits, economic, and cultural rights for rural communities. In other words, land use has a variety of functions which is the integration between the natural functions of forests and functionality to meet the social, economic, cultural community (who live around the forest). These functions, among others, is a function of soil to resist erosion, regulate hydrological systems, germplasm conservation, and provide a positive effect on microclimate. Another function that is not less important is to provide socio-economic functions that are very important to the rural people, for example, produces food production to sustain the daily needs of the population (subsistence), or in commercial production.

Agroforestry has long been widely practiced in Indonesia. In fact, regarded as the embodiment of authentic Indonesian culture that has been modified and able to adapt to changing biophysical and socioeconomic communities. On the island of Java, known for various forms of agroforestry, among others: (1) fruit trees-growing in dry fields; in West Java known as Huma, (2) mix garden system or Talun called Krakal in Purworejo, Central Java, and gardens in Malang, East Java, and (3) Kebun Talun system in West Java (Soemarwoto and Soemarwoto, 1984).

In general, agroforestry land planted by diverse types of crops (annual) and perennials or annual (perennial). The species that make up the very bottom is the type of vines at ground level, such as sweet potato (Ipomoea batatas), while at the top there is a bush plant that has a height less than $1 \mathrm{~m}$, at the top is filled by other types of plants that 1-2 $\mathrm{m}$ tall, then other types of plants that has a height of 2-5 m, in the deeper layers of structured types of fruit trees, firewood, and building materials, and the top layer is filled by the type of plant that has a height of more than $8 \mathrm{~m}$. Two of the factors that can distinguish 
systems of agricultural production in agroforestry systems is the state and type of plants. Like the garden, generally dominated by annual crops and intensive treatment (Iskandar, 2001).

Based on the description above, agroforestry is the concept of integrated land management based on the forestry sector, combined with agriculture, livestock, or fisheries. Agroforestry is to cultivate the land by multistrata plant. Not only with plants but can also combined with animal husbandry and fisheries. The selection of plants and planting layout is a key success of this concept. Multi-strata is the use of land with different crops to plant such as lower-strata vegetation (emponempon, tubers, grass for animal feed), saplings or seasonal vegetation (bananas, papaya, mango, rambutan, durian), and tree vegetation that need decades to grow.

Application of the concept of agro-forestry in land management can provide benefits economically, ecologically, socially, and culturally. With a variety of cultivated plants can provide good income for the community on a daily, monthly, annual, seasonal, and decades. It depends on the pattern adopted agro-forestry. Agrisilvikultur (forestry-agriculture), silvopastura (forestry, animal husbandry), agrisilvopastura (forestryagricultural-livestock), silvofishery (forestry, fisheries), apiculture (bee-forestry), Sericulture (silkwormforestry), or multipurpose forest tree production system (fusion complex). Ecologically, agroforestry support soil and water conservation. With multi-strata plants will certainly minimize the occurrence of erosion, reduce run off and increase the effectiveness of water infiltration. Spatial patterns of agro-forestry can also allow its function as a wind-breaker.

Socially, agroforestry can provide good jobs in land management and processing of crop products. Variations of agricultural strengthen local community food security system. So people do not have to worry about price increases or shortages of certain basic commodities. The agroforestry products provide supply of wood building materials. Agroforestry is how we put the right types of plants, in appropriate locations, and with good reason. Agroforestry is increasingly recognized as a pattern approach to natural resource management in a sustainable manner, incorporating the purpose of protection, agriculture, and development. Among these benefits is the contribution to the conservation of native biodiversity. Although the protection of natural habitat remain the backbone of biodiversity conservation strategies, at least agroforestry also support the role.
Multi-strata planting allows the selection of rare species of plant or endemic plants to be cultivated again. This is useful as a germplasm protection of biodiversity. Types of crops and cropping patterns provide living space for micro-habitat for many wildlife species. Butterflies need specific plants as hosts. Several species of flowering plants are able to invite the presence of various types of insects and birds. Types of fruit trees provide food reserves for birds and herbivorous mammals. Increased production of litter can improve soil fertility and enhance soil insects. Agroforestry maintain the stability of the material production of the type of producer to support the food chain in the balance of ecological systems. Good food chain supporting the recycling of energy and material are important. That would keep the balance of the ecosystem. With a variety of benefits to be derived from the application of agro-forestry, putting this concept to be worth a try as an alternative concept of watershed management, especially the upper with an integrated management system and involves multistakeholder

\section{Decision Making Process in Agroforestry}

In the decision making process related to agroforestrym there is an interesting fact that women also involeved in the process. In the Sundanese people who adhered to the lineage of two sides (bilateral), the decision making process can be done by the father, mother, or both.

\section{Table 1. Decision Making in the Kebun Talun $(\mathbf{N}=27)$}

For example, for children's education decision-making, the family (father and mother) will decide together. Usually in this case, the father was the one who determines the final decision. Another case, to determine the diet of the family, although the mother is considering proposals from the father or other family members, but the final decision is usually made by the mother.

The interesting findings in the field is that women is involved in the decision-making to save money from the sale of agricultural crops. These conditions indicate that there is still important role played by women in the domestic sector. Again, the issue of women's multiple roles re-appear in the case of the increasing role of women in the public sector. This condition occurs because of the increased role of women in the public sector is not accompanied by a reduction in the role of women in the domestic sector, or in many cases, not accompanied by the willingness of men to get involved in activities in the domestic sector. 


\section{METHOD}

To be able to obtain more complete data, this research uses qualitative and quantitative methods. For example, quantitative data on the various cultivated trees/crops is strengthened by qualitative data on how the decisionmaking in the family to determine the harvest time. Data collection using observation and interview, both with list of question that analyze by statistical program and depth interview. Sampling in the survey is based on Lynch formula, 1974.

$$
\begin{array}{ll}
n=\quad & N \cdot Z^{2} \cdot P(1-P) \\
& N \cdot d^{2}+Z^{2} \cdot P(1-P)
\end{array}
$$

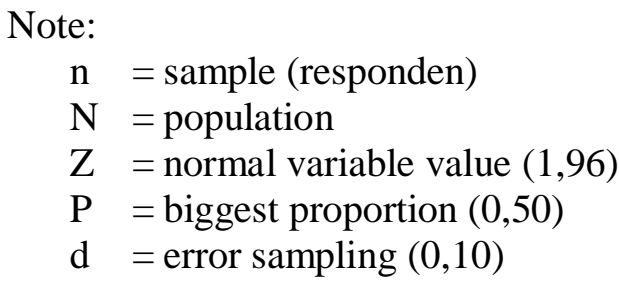$$
\text { (Lynch et.al., 1974) }
$$

From the formula above, when the population in the study site is 7,911 , then the representative sample of the population is 111. Interviews with questionnaire is conducted to 111 respondents. Meanwhile, in-depth interviews with interview guides is addressed to 3 key informants.

\section{RESULTS}

\section{Comodities from Agroforestry in Tunagan}

The result of the study shows the high variation of cultivated trees and crops in the practice of agroforestry by people in Tunagan, Cianjur. Some of the variation are showed in Table 2, below. With the types of plants that are quite varied has caused the different phase of agricultural work. For example, in the case of bamboo, the peasants only cultivated bamboo once in five to seven years. Then thera are ginger and curcuma which the peasants only planted once a year. Also, there are crops such as chilies, peanuts, and upland paddy, which are planted for three to six months.

\section{Table 2. Type of commodities from agroforestry}

The different planting period/phase created different harvesting phases. For bamboo and other timber trees, the harvest time is in three to seven years. The harvest time for ginger and curcuma are once a year. While the harvest time for crops are almost throughout the year.

\section{Table 3. Harvesting Period of the Cultivated Trees/Crops in Agroforestry}

According to the above table, it appears tha the peasants can harvest more than once a year. For example, in September or October they began clearing land for planting ginger or curcuma in one part of land. Then in February they began planting chilies and chives. Chives have a fairly short growing season of around three months, so that farmers can harvest chives in May or June. Then in August, the farmers began to harvest chili. Unlike chives that can only harvest for one time, chili can be harvested several times in a year.

\section{DISCUSSION}

In addition to meet the needs of the household, Tunagan peasant also sell crops from agroforestry systems. Although the market located quite far with the inadequate transportation infrastructure and also expensive, Tunagan peasant had no difficulty in selling their crops. Tunagan farmers usually sell their product directly to the bandar that come directly to their home or farm to buy the crop.

Similar with previous studies on agroforestry, the diversity of plant species in agricultural practices can greatly support ecosystem services. Ecosystem services from agroforestry nearly resembles the ecosystem services that forests can be given. In addition, agroforestry practices also provide economic benefits for the peasant. With the various types of commodities that can be sold at different times, farmers Tunagan have a chance to get cash at different times. These conditions support the high financial security of Tunagan Peasant, compare with the peasant who only depend on one type of commodity.

Most of informants said that the money they get from selling the crop, usually used to buy daily necessities. However, people of Tunagan also have the local financial system. For people who have cash, they usually keep the money in local bank system or spend it for the consumption goods or for investment such as motorcycles, cattle, or gold (jewelry). Purchase or 
transaction of goods is also conducted by the local banks. This happens because the cost of transportation from Kampung Tunagan to the market or shops nearby is very expensive. If the cash is not enough to buy the goods that they want, the local banks offer installments. Then, farmers must pay the installments. Installment period can be adjusted to the ability of farmers. It can be daily, weekly, or monthly. To pay the installment, they do not need to bother to go to the bank office, the bank officer will come to collect it. Besides being able to save money, buy goods or to investment, Tunagan farmers can borrow money from the local banking system. The payment system is also approximately the same with the installment of purchasing goods. Farmers can adjust the amount of installment and the period.

“...euleuh-euleuh itu si Kasep tos sumping geuning. Euhhh meni ararisin aya si Ibu.. keheula nya Kasep urang kokoreh heula, sabaraha kali deui atuh bade disumpingan ku si Kasep teh?!'

(euleuh-euleuh ada yang kasep (tampan) sudah datang. Euhhhh jadi malu ada Ibu (penulis).. sebentar ya saya cari dulu, berapa kali lagi si kasep bakalan dateng kesini teh?).

(hey there come the handsome guy, you humiliate me in front of Ibu (author). Wait I have to look for the money first. How many time you will visit me again, handsome guy? --- it means how many more times she should pay the debt).

The above statement disclosed by an informant when the local bank officer came to collect repayments. Typically, an officer has a certain working area from time to time. The high intensity interaction between the bank officer and farmers is creating a close relationship between them.

\section{CONCLUDING REMARK}

Agroforestry system has its benefit for the environment. With the high variaton of cultivated trees and crops in agroforestry system, the ecosystem services from this system are nearly the same with the services from forest. In another way, the variation of cultivated tees and crops in agroforestry also provide high variation of economic benefit to the peasant in Tunagan. People of Tunagan who live in the, let's say, isolated area, due to the dificulties of reaching this area, usually use banking services from this local banking system. The local banking system does not only provide the banking transaction, but also offer the mimicry of family bound between the bank officer and the customer.

\section{ACKNOWLEDGEMENT}

The author would like thank Professor Tohji Kazuyuki and Professor Kimura Yoshihiro from Post Graduate Study on Environmental Studies Tohoku University, Japan for their supervision and financial support during the research. I would like to also thank colleague and friends in Department of Anthropology FISIP and IMM Program FEB, Padjadjaran University.

\section{REFERENCE}

Iskandar, J. Manusia Budaya dan Lingkungan: Kajian Ekologi Manusia.’Humaniora Utama Press. Bandung.2001.

Soemarwoto, Otto dan Idjah Soemarwoto. "The Javanesse Rural Ecosystem." In A. Terry Rambo dan Percy E. Sajise (eds.), An Introduction to Human Ecology Research on Agricultural System in Southeast Asia. University of the Philippines. Los Banos. 1984.

Christanty, Linda. "Without Bamboo, the Land Dies: Biomass, Litterfall, and Soil Organic Matter Dynamic of a Javanesse Bamboo Talun Kebun System." Forest Ecology and Management. 87: 75-88. 1996.

Wiyanti, Dede T. 2015. "Role of Women in Kebun Talun System in Karamatmulya Village, Soreang. Sosiohumaniora Vol. 17, No. 3, November 2015. 
Table 1. Decision Making in the Kebun Talun $(\mathbf{N}=\mathbf{2 7})$

\begin{tabular}{|c|c|c|c|c|c|c|c|c|}
\hline \multirow[t]{2}{*}{ Type of Decision Taken } & \multicolumn{2}{|c|}{ Women Only } & \multicolumn{2}{|c|}{ Men Only } & \multicolumn{2}{|c|}{ Dominant Women } & \multicolumn{2}{|c|}{ Dominant Men } \\
\hline & Number & $\%$ & Number & $\%$ & Number & $\%$ & Number & $\%$ \\
\hline Type of plant & A & 3.70 & 6 & $22: 22$ & NA & & 15 & 55.56 \\
\hline Time of planting & A & 3.70 & 6 & $22: 22$ & NA & & 15 & 55.56 \\
\hline Division of labor between men and women (who does what) & A & 3.70 & 6 & $22: 22$ & NA & & 15 & 55.56 \\
\hline Solving problems that arise (if any) & A & 3.70 & 4 & 14.81 & NA & & 17 & 62.96 \\
\hline When to harvest & A & 3.70 & 3 & $11: 11$ & NA & & 18 & 66.67 \\
\hline Designated harvest (stored, consumed, and / or sold) & A & 3.70 & 3 & 11:11 & 3 & 11:11 & 15 & 55.56 \\
\hline Where / to whom the harvest is sold & A & 3.70 & 8 & 29.63 & NA & & 13 & 48.15 \\
\hline Who is selling & A & 3.70 & 9 & 33.33 & NA & & 12 & 44.44 \\
\hline Who would save money from the sale of crops & 8 & 29.63 & 3 & $11: 11$ & 10 & 37.04 & A & 3.70 \\
\hline Who is using money from the sale of crops & 2 & 7:41 & 3 & 11:11 & 12 & 44.44 & 5 & $18: 52$ \\
\hline
\end{tabular}

Sources: Wiyanti, 2008

Table 2. Type of commodities from agroforestry

\begin{tabular}{|c|c|c|c|}
\hline \multicolumn{5}{|c|}{ Name of Crops/Trees from Agroforestry } & English \\
\hline Sundanese & Indonesia & Umbrella tree & Maesopsis eminii \\
\hline Afrika & kayu afrika & Bamboo & bambusa spinoza \\
\hline Awi & Bamboo & Albizia & Albizia falcataria \\
\hline Jeunjing & Albasia & Calliandra & Calliandra calothyrsus \\
\hline kaliandra & Kaliandra & Ginger & Zingiber officinale \\
\hline Jahe & Jahe & Chilli & Capsicum annuum \\
\hline Cengek & cabe rawit & geanut, groundnut & Arachis hypogaea \\
\hline kacang suuk & kacang tanah & garlic & Allium tuberosum \\
\hline Kucai & Kucai & Cassava & Manihot utilissima \\
\hline Sampeu & singkong, ketela pohon, ubi kayu & turmeric, curcuma & Curcuma longa \\
\hline Koneng & Kunyit & &
\end{tabular}

Source: Survey, 2015

Table 3. Harvesting Period of the Cultivated Trees/Crops in Agroforestry

\begin{tabular}{|c|c|c|}
\hline & Name of trees/plants & \multirow{2}{*}{ Harvesting period } \\
\hline Sundanese & Latin & $3-5$ years \\
\hline Afrika & Bambusa spinoza & $3-7$ years \\
\hline Awi & Albizia falcataria & $3-5$ years \\
\hline Jeunjing & Calliandra calothyrsus & $3-5$ years \\
\hline Kaliandra & Zingiber officinale & $1-1.5$ months \\
\hline Jahe & Capsicum annuum & $3-4$ months \\
\hline Cengek & Arachis hypogaea & 4 months \\
\hline kacang suuk & Allium tuberosum & 3 months \\
\hline Kucai & Manihot utilissima & $6-12$ months \\
\hline Sampeu & Curcuma longa & $1-1.5$ years \\
\hline Koneng & & \\
\hline
\end{tabular}

Source: Survey, 2015. 